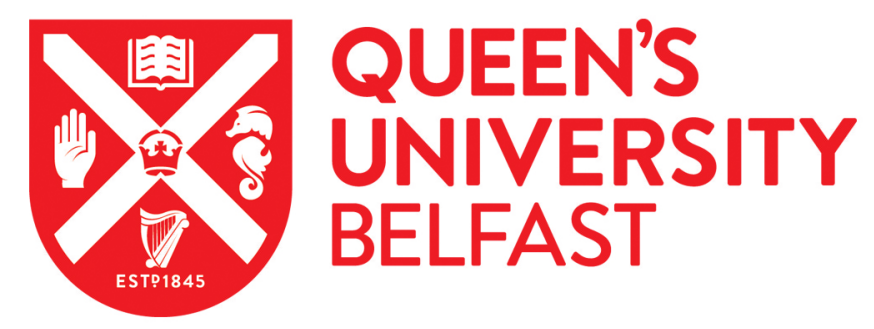

\title{
Do phytoestrogens reduce the risk of breast cancer and breast cancer recurrence? What clinicians need to know.
}

Velentzis, L. S., Woodside, J., Cantwell, M., Leathem, A. J., \& Keshtgar, M. R. (2008). Do phytoestrogens reduce the risk of breast cancer and breast cancer recurrence? What clinicians need to know. European journal of cancer (Oxford, England : 1990), 44(13), 1799-1806. https://doi.org/10.1016/j.ejca.2008.05.019

Published in:

European journal of cancer (Oxford, England : 1990)

Queen's University Belfast - Research Portal:

Link to publication record in Queen's University Belfast Research Portal

\section{General rights}

Copyright for the publications made accessible via the Queen's University Belfast Research Portal is retained by the author(s) and / or other copyright owners and it is a condition of accessing these publications that users recognise and abide by the legal requirements associated with these rights.

Take down policy

The Research Portal is Queen's institutional repository that provides access to Queen's research output. Every effort has been made to ensure that content in the Research Portal does not infringe any person's rights, or applicable UK laws. If you discover content in the Research Portal that you believe breaches copyright or violates any law, please contact openaccess@qub.ac.uk. 


\title{
Review
}

\section{Do phytoestrogens reduce the risk of breast cancer and breast cancer recurrence? What clinicians need to know}

\author{
Louiza S. Velentzis ${ }^{a, *}$, Jayne V. Woodside ${ }^{b}$, Marie M. Cantwell ${ }^{b}$, Anthony J. Leathem ${ }^{a}$, \\ Mohammed R. Keshtgar \\ ${ }^{a}$ University College London, Department of Surgery, Breast Cancer Research Group, Charles Bell House, 67-73 Riding House Street, \\ London W1W 7EJ, UK \\ ${ }^{\mathrm{b}}$ Centre for Clinical and Population Sciences, Lower Ground Floor, Pathology Building, Grosvenor Road, Belfast BT12 6BJ, UK \\ ${ }^{\mathrm{C}}$ Department of Surgery, Royal Free Hospital, Pond Street, London NW3 2QG, UK
}

\section{A R T I C L E I N F O}

\section{Article history:}

Received 13 April 2008

Received in revised form

26 May 2008

Accepted 29 May 2008

Available online 7 July 2008

Keywords:

Phytoestrogens

Soy

Lignans

Breast cancer

Recurrence

Survival

Supplements

\begin{abstract}
A B S T R A C T
Oestrogen is an important determinant of breast cancer risk. Oestrogen-mimicking plant compounds called phytoestrogens can bind to oestrogen receptors and exert weak oestrogenic effects. Despite this activity, epidemiological studies suggest that the incidence of breast cancer is lower in countries where the intake of phytoestrogens is high, implying that these compounds may reduce breast cancer risk, and possibly have an impact on survival. Isoflavones and lignans are the most common phytoestrogens in the diet.

In this article, we present findings from human observational and intervention studies related to both isoflavone and lignan exposure and breast cancer risk and survival. In addition, the clinical implications of these findings are examined in the light of a growing dietary supplement market. An increasing number of breast cancer patients seek to take supplements together with their standard treatment in the hope that these will either prevent recurrence or treat their menopausal symptoms. Observational studies suggest a protective effect of isoflavones on breast cancer risk and the case may be similar for increasing lignan consumption although evidence so far is inconsistent. In contrast, short-term intervention studies suggest a possible stimulatory effect on breast tissue raising concerns of possible adverse effects in breast cancer patients. However, owing to the dearth of human studies investigating effects on breast cancer recurrence and survival the role of phytoestrogens remains unclear. So far, not enough clear evidence exists on which to base guidelines for clinical use, although raising patient awareness of the uncertain effect of phytoestrogens is recommended.
\end{abstract}

(c) 2008 Elsevier Ltd. All rights reserved.

\section{Introduction}

In addition to the known risk factors for breast cancer, such as inheritance of susceptibility genes, environmental factors are thought to influence the risk and progression of breast cancer. Epidemiological data have demonstrated that breast cancer, in the descendants of women who have migrated from countries of low breast cancer incidence, reaches the

\footnotetext{
* Corresponding author: Tel.: +44 207679 9049; fax: +44 2076709047.

E-mail address: l.velentzis@ucl.ac.uk (L.S. Velentzis).
}

0959-8049/\$ - see front matter @ 2008 Elsevier Ltd. All rights reserved.

doi:10.1016/j.ejca.2008.05.019 
higher incidence rate of the host country as women adopt new dietary and lifestyle patterns. ${ }^{1}$ Consumption of a diet rich in soy-containing foods, known to be rich in phytoestrogens, is proposed to be one of the chemoprotective factors against breast cancer in Asian populations and intake is much lower in countries with higher rates of breast cancer.

Phytoestrogens are polyphenolic plant chemicals that share common structural features with the mammalian oestrogen 17-oestradiol, enabling them to bind to the oestrogen receptor. There is also evidence that phytoestrogens have hormone-independent activities which are listed in Table 1.

\section{Sources and metabolism}

The two most studied families of phytoestrogens related to diet are isoflavones and lignans. Isoflavones are found in legumes particularly soya beans, traditional soya derived foods like tofu and analogues of Western type foods such as soya milk. Red clover and other herbs rich in isoflavones are usually consumed in the form of a supplement. Lignans, the other main phytoestrogen family, are found in the woody portions of fruit and vegetable, in seed coats and in grain bran of fibre-rich cereals. ${ }^{2}$ The main source of phytoestrogens in the Asian diet is isoflavones whereas the Western diet is richer in lignans. The chemical structure of these compounds in comparison with oestradiol is shown in Fig. 1.

Phytoestrogens are derived from parent compounds after complex enzymatic processes that occur in the liver, intestine and colon. These processes are important for their metabolism but may also be important for their biological activity as more potent (oestrogenic and anti-oestrogenic) chemicals

Table 1 - Proposed isoflavone and lignan anti-carcinogenic mechanisms of action independent of oestrogen receptor binding

Mechanisms of action of phytoestrogens

\begin{tabular}{lcc}
\hline Mechanism of Action & Isoflavones & Lignans \\
\hline Mechanisms with direct hormonal effect & & \\
5- $\alpha$-reductase inhibition & $\sqrt{ }$ & $\sqrt{ }$ \\
17- $\beta$-hydroxysteroid dehydrogenase & $\sqrt{ }$ & \\
inhibition & & $\checkmark$ \\
Aromatase inhibition & $\sqrt{ }$ & $\sqrt{ }$ \\
Alteration in SHBG levels & $\sqrt{ }$ & $\sqrt{ }$ \\
Alteration in oestrogen metabolite & & \\
ratios & $\sqrt{ }$ & \\
Sulphatase and sulphotransferase & & \\
inhibition & & \\
Mechanisms of no hormonal effect & $\sqrt{ }$ & \\
Anti-oxidant & $\sqrt{ }$ & \\
Cell adhesion effects & $\sqrt{ }$ \\
DNA topoisomerase inhibition & $\sqrt{ }$ \\
Enhancement of immune system & & \\
function & $\sqrt{ }{ }^{63,64}$ & \\
Inhibitory effect on cell invasion & $\sqrt{ }$ & \\
Inhibition of angiogenesis & $\sqrt{ }$ \\
Tyrosine kinase inhibition & & $\sqrt{ }$ \\
Inhibition of tumour metastasis & & \\
\hline Modified from Piersen. ${ }^{62}$ & & \\
\hline
\end{tabular}<smiles>COc1cc(O)ccc1C1CCC2C1CCC1(C)C(O)CCC21</smiles><smiles>O=c1c(-c2ccc(O)cc2)coc2cc(O)ccc12</smiles><smiles>COc1cc(CC2COC(=O)C2Cc2ccc(O)c(OC)c2)ccc1O</smiles>

Matairesinol<smiles>OCC(CO)C(CO)Cc1cccc(O)c1</smiles>

Enterodiol

Fig. 1 - Chemical structures of oestradiol, the isoflavone daidzein, the plant lignan matairesinol and the mammalian lignan enterodiol.

are produced; for example, the isoflavone daidzein is converted to the more oestrogenic compound equol. ${ }^{3}$

Metabolism of phytoestrogens can vary greatly between individuals even when exact amounts of phytoestrogen-containing food have been ingested. ${ }^{4}$ This could be due to factors affecting the chemical composition of the natural food. For example, the location, climatic conditions and genetics of the plant have been shown to influence the concentration of isoflavones in the raw soya bean. ${ }^{2}$ The microbial composition of the intestinal flora may also play a role in inter-individual variation and antibiotic use in humans has been shown to reduce excretion of isoflavone metabolites. ${ }^{5}$ Duration and time of exposure to antibiotics during one's lifetime, gender, age and background diet may also contribute to interindividual variation. ${ }^{4}$

\section{Isoflavones and breast cancer risk}

Epidemiological studies have investigated the association between isoflavones and breast cancer risk by measuring dietary isoflavone intake, or levels of these in plasma/serum or urine, while some studies have looked at soy and breast cancer risk measuring exposure to soy-containing foods such as tofu and miso soup. Recently, Wu and colleagues ${ }^{6}$ conducted two separate meta-analyses of studies carried out in Asian and Western populations to take into account the great variation in isoflavone intake between these two populations. Results from the meta-analysis of eight studies showed that pre- and post-menopausal Asian women consuming the highest amount ( $\geqslant 20 \mathrm{mg} / \mathrm{d}$ ) of dietary isoflavones had a $29 \%$ reduction in breast cancer risk when compared to low-level isoflavone Asian consumers ( $\leqslant 5 \mathrm{mg} / \mathrm{d}$ ). A dose-response relationship was also demonstrated for a moderate isoflavone intake of $10 \mathrm{mg} / \mathrm{d}$ which resulted in a $12 \%$ decrease in risk. In contrast, the meta-analysis of 11 studies carried out in women with Western diets found no association between isoflavone intake and breast cancer risk (median of highest intake was $0.8 \mathrm{mg} / \mathrm{d}$ and of lowest intake was $0.15 \mathrm{mg} / \mathrm{d}$ ). 
Two earlier meta-analyses ${ }^{7,8}$ also showed a protective effect of isoflavone consumption with an overall odds ratio of 0.86 [95\% confidence interval (CI) 0.75-0.99], and a relative risk of 0.75 (CI 0.59-0.95), respectively. Unlike Wu and colleagues, ${ }^{6}$ these meta-analyses included studies which had incomplete measurement of total isoflavone intake as only certain soy foods were assessed from the diet. Furthermore, Trock and colleagues $^{7}$ included studies where exposure to isoflavones was also estimated by urinary measurement rather than dietary questionnaires alone and calculated the estimated dietary intake from urinary excretion.

It is also worth noting three case-control studies which have researched the effects of isoflavone intake during adolescence on breast cancer risk later on in life. A Canadian study $^{9}$ and two others conducted in Asian women ${ }^{10,11}$ have shown a decrease in breast cancer risk with high intake of isoflavones during adolescence. Although the specific time period during which diet can affect breast cancer risk in humans has not been identified, breast tissue during adolescence has been shown to be more susceptible to carcinogens than in adults. In animal studies, early exposure to genistein reduces the number of terminal end buds which have many undifferentiated epithelial cells and increases the number of lobules which have more differentiated cells and are therefore less susceptible to carcinogens. ${ }^{12}$

\section{Breast cancer risk and plant/mammalian lignans}

Unlike studies of the effects of isoflavones, the majority of studies on lignans have taken place in non-Asian populations mainly owing to the higher consumption of lignan-containing foods in Western diets. Lignans found in food are called plant lignans whereas their metabolic products in humans and animals are called mammalian lignans. The most studied of these compounds in relation to breast cancer have been the mammalian lignans enterolactone and enterodiol. Exposure has been investigated by blood and urine analysis as well as dietary intake assessment.

\subsection{Dietary intake of lignans and breast cancer risk}

Seven retrospective case-control studies have investigated dietary intake of lignans and breast cancer risk. ${ }^{9,13-18}$ of these, one study has investigated the effect of dietary intake during adolescence ${ }^{9}$ reporting a protective effect in adulthood for high plant lignan intake early in life. A US study ${ }^{18}$ of nonAsian Americans has shown no association between plant lignan levels and breast cancer risk. All other case-control studies have shown a protective role. ${ }^{13-17}$ Of three prospective studies carried out, an American study ${ }^{19}$ has shown no effect for plant lignan matairesinol and a non-significant increased risk associated with high intake of the plant lignan secoisolariciresinol. However, adjustment for wine intake, a rich source of this plant lignan, attenuated this increase in risk. A Dutch study ${ }^{20}$ showed a non-significant inverse association between breast cancer risk and mammalian lignan intake while a more recent study ${ }^{21}$ using a French postmenopausal cohort showed a significant protective effect of lignan intake which was limited to oestrogen receptor (ER) and progesterone receptor (PR) positive tumours. This finding would support the idea that lignans have some mechanism of action at the level of the hormone receptor.

\subsection{Blood concentrations of lignans and breast cancer risk}

Assessment of intake using dietary questionnaires and food databases can be very time consuming and sometimes inaccurate. Serum or plasma levels of phytoestrogens have been shown to significantly correlate with dietary intake $e^{22,23}$ and their measurement can therefore be used as an alternative, more objective method for estimating exposure.

There have been nine epidemiological studies looking at blood levels of lignans and breast cancer risk. Four have shown no association, ${ }^{22-26}$ one study has shown a positive association ${ }^{27}$ while four others have shown a protective effect. ${ }^{28-31}$ It is interesting to note that a Swedish study ${ }^{27}$ found an increased risk of breast cancer with both very low and very high enterolactone levels but not with medium levels, indicating a U-shaped relationship. Many studies look for a linear trend statistically making it possible for U-shaped relationships to be overlooked. It is also worth noting that the protective effect of plasma enterolactone on breast cancer risk demonstrated by the Danish study ${ }^{29}$ was restricted to ER $\alpha$ negative tumours only. This finding is supported by another study ${ }^{32}$ reporting a protective effect for ER negative tumours with increased plant lignan intake but opposite to the findings by Touillaud and colleagues ${ }^{21}$ discussed above.

\subsection{Urinary concentrations of lignans and breast cancer risk}

Aside from using blood, urine can also be used to investigate exposure. Phytoestrogen levels in both $24 \mathrm{~h}$ urine collections and spot urine samples have been shown to correlate well with dietary intake. ${ }^{22,23}$

Six separate studies have examined the effect of urinary excretion of lignans on breast cancer risk. The results are again inconsistent; one study reported no association, ${ }^{23}$ one reported a non-significant increase in risk with increasing lignan concentrations ${ }^{33}$ whereas four have shown a protective effect. $^{34-37}$

\subsection{Summary}

Overall, there is some epidemiological evidence of increased isoflavone and lignan intake being associated with a reduced risk of breast cancer but it is, inconsistent. Possible reasons for this include differences in populations investigated (Asian and non-Asian), sample size, study designs and adjustment for different confounding factors. Focus on investigating only certain sub-groups of breast cancer patients based on menopausal or receptor status versus the whole population can also add to the complexity. Furthermore, there are inherent problems with each method of measuring exposure such as the use of different and incomplete dietary databases, sensitivity and comparability of sample analysis techniques (e.g. time resolved fluorescence, gas chromatography/mass spectrometry) and methods of intake assessment (e.g. validated 
and non-validated questionnaires). Variation in phytoestrogen metabolism owing to differences in intestinal microflora, and possibly the genetic make-up of participants ${ }^{14}$ may also need to be considered when comparing data across studies. The timing of exposure to lignans, as well as isoflavones, may be important in elucidating their role in breast cancer risk. Evidence from one retrospective study ${ }^{9}$ showing a protection in adulthood when lignans were consumed in adolescence needs to be confirmed.

\section{Human intervention studies and breast cancer}

There have been relatively few human intervention studies exploring the possible link between phytoestrogens and breast cancer. The effect of supplementation on breast cell proliferation has been investigated in six trials ${ }^{38-43}$ (see summary Table 2). Studies were small, varied in the type of intervention used and the type of subjects, having either healthy women, breast cancer patients or a combination of breast cancer patients and women with benign breast disease. Study duration was short in all studies except one ${ }^{43}$ where the intervention lasted for 12 months.

Three studies reported oestrogenic stimuli ${ }^{38-40}$ following isoflavone supplementation, which may be associated with an increased risk of breast cancer. This was demonstrated by appearance of hyperplastic epithelial cells ${ }^{38}$ in nipple aspirate fluid, increased proliferation of lobular breast epithelium cells, up-regulation of progesterone receptor expression ${ }^{39}$ and changes in oestrogen-regulated proteins. ${ }^{40}$ There are also three trials which have reported no difference in cell proliferation between intervention and control groups ${ }^{41-43}$ although one of these has only published preliminary data. ${ }^{42}$ Only one study has reported a potentially protective effect; ${ }^{44}$ unlike other studies, the intervention used was lignan-rich flaxseed. Comparative examination of tumour tissue from core biopsy and surgery showed a significant reduction in tumour cell proliferation, an increase in apoptosis and a decrease of c-erbB2 (HER2) in the flaxseed-eating group only.

The mammographic density of the breast is considered a predictor of breast cancer risk. ${ }^{45}$ Consequently, the effect of phytoestrogen supplementation on breast density has been investigated in several intervention studies. Two doubleblind, placebo controlled studies ${ }^{46,47}$ found no significant difference in percent density between the control group and the isoflavone-consuming group after 1 year. A longer 2-year study ${ }^{48}$ carried out in ethnically diverse Hawaiian subjects also failed to show any significant difference in mammographic outcome between women supplementing their diet with soy foods and those on a regular diet. However, as lifetime soy intake was also assessed, the authors found that women who consumed soy throughout their lifetime had higher percent densities than those who ate no soy but this was only observed in Caucasian and not Asian women. No intervention trial has studied lignan supplemention on mammographic patterns; however, a large cross-sectional study carried out in Norway ${ }^{49}$ found that higher levels of enterolactone in the blood were associated with a slight increase in breast density. In another study, ${ }^{50}$ a protective effect for high dietary intake of plant lignan secoisolariciresinol was demonstrated but as the sample size was small these results need to be confirmed by larger studies.

\section{Phytoestrogens, breast cancer recurrence and survival}

The relationship between phytoestrogen intake and breast cancer recurrence and survival has yet to be evaluated. Two studies have explored pre-diagnosis phytoestrogen intake and breast cancer survival. In a study conducted in the US ${ }^{51}$ dietary intake of isoflavones was assessed by a food frequency questionnaire in 1210 newly diagnosed pre- and post-menopausal breast cancer patients. The authors reported a $48 \%$ lower risk of all-cause mortality for the highest versus lowest quintile of isoflavone intake [hazard ration 0.52 , 95\%CI (0.33-0.82)]. A similar reduction in risk was found for breast cancer mortality but it was limited to postmenopausal women.

The second study was conducted in an Asian population. ${ }^{52}$ Dietary information during a 5-year period prior to diagnosis was collected from 1459 Chinese breast cancer patients (both pre- and post-menopausal) using a validated questionnaire. After a 5-year follow-up period, no overall association was reported between soy intake (either as total soy protein or as total isoflavone) prior to cancer diagnosis and disease-free breast cancer survival [adjusted hazard ratio 0.99 (95\% CI 0.73-1.33)] for women in the highest tertile of intake compared with those in the lowest tertile. The association remained the same regardless of ER/PR status, TNM staging, age at diagnosis, body mass index, waist to hip ratio and evaluation for genetic polymorphisms for ER $\alpha$ and ER $\beta$.

There is a pressing need for further work in this area to evaluate the safety and potential interactions of phytoestrogen use with hormonal breast cancer treatments. Animal work has shown that the anti-proliferative action of tamoxifen is negated in the presence of low doses of genistein but retained in high doses. ${ }^{53}$ Such interactions have not yet been examined in any human studies.

A prospective cohort study investigating the effects of phytoestrogens (DietCompLyf study) in breast cancer survivors is being conducted by our group at University College London. The study's aim is to assess the relationship between phytoestrogen exposure after diagnosis and survival. Breast cancer patients enter the study 1 year after diagnosis of primary invasive breast cancer. Information is then collected on dietary intake, lifestyle behaviours, use of supplements and complementary therapies both prior to diagnosis and during an additional 4-year follow-up period. Urine and blood samples are also collected for phytoestrogen analysis by UPLCMS (ultra performance liquid chromatography-mass spectrometry). Recruitment of 3000 patients is anticipated to be completed by 2010.

\section{Emerging phytoestrogen supplement market}

A number of phytoestrogen-containing supplements have flooded the market in the last decade marketed as safe 
Table 2 - Phytoestrogen intervention studies in humans investigating effects on breast cell proliferation

\begin{tabular}{|c|c|c|c|c|c|}
\hline Author, year & $\begin{array}{l}\mathrm{PE}^{\mathrm{a}} \text { source and } \\
\text { dose }\end{array}$ & $\begin{array}{c}\text { Sample sizes, study } \\
\text { details }\end{array}$ & Study duration & Results & Comments \\
\hline $\begin{array}{l}\text { Petrakis et al., } \\
1996 \text { (38) }\end{array}$ & $\begin{array}{l}38 \mathrm{mg} / \mathrm{d} \text { of genistein } \\
\text { (form: soy protein } \\
\text { isolate) }\end{array}$ & $\begin{array}{l}24 \text { healthy women (14 } \\
\text { pre- and } 10 \\
\text { postmenopausal). } \\
\text { Needle aspirate fluid } \\
\text { obtained monthly and } \\
\text { examined cytologically }\end{array}$ & $\begin{array}{l}12 \text { months of which } 6 \\
\text { had intervention } \\
\text { (from } 4^{\text {th }} \text { to } 9^{\text {th }} \\
\text { month) }\end{array}$ & $\begin{array}{l}7 \text { of the } 24 \text { women } \\
\text { developed hyperplastic } \\
\text { epithelial cells after } \\
\text { intervention. Volume } \\
\text { of fluid aspirate } \\
\text { increased in } \\
\text { premenopausal } \\
\text { women only during } \\
\text { and after soy } \\
\text { supplementation }\end{array}$ & $\begin{array}{l}\text { Inter-individual } \\
\text { variability minimised } \\
\text { owing to crossing } \\
\text { over design of study }\end{array}$ \\
\hline $\begin{array}{l}\text { McMichael- } \\
\text { Phillips et al., } \\
1998 \text { (39) }\end{array}$ & $\begin{array}{l}45 \mathrm{mg} / \mathrm{d} \\
\text { isoflavones(form: } \\
\text { soy protein) }\end{array}$ & $\begin{array}{l}48 \text { premenopausal } \\
\text { women ( } 9 \text { with breast } \\
\text { cancer and the rest } \\
\text { with benign breast } \\
\text { disease). Randomised } \\
\text { design. } 19 \text { patients } \\
\text { received soy }\end{array}$ & $14 \mathrm{~d}$ prior to surgery & $\begin{array}{l}\text { increase in breast } \\
\text { epithelial cell number } \\
\text { and progesterone } \\
\text { receptor expression in } \\
\text { soy-treated patients }\end{array}$ & $\begin{array}{l}\text { Details of recent } \\
\text { antibiotic use } \\
\text { collected }\end{array}$ \\
\hline $\begin{array}{l}\text { Hargreaves } \\
\text { et al., } 1999(40)\end{array}$ & $\begin{array}{l}45 \mathrm{mg} / \mathrm{d} \text { isoflavones } \\
\text { (form: soy protein) }\end{array}$ & $\begin{array}{l}28 \text { women randomised } \\
\text { to received intervention } \\
\text { and } 23 \text { acted as } \\
\text { controls. Majority of } \\
\text { patients had benign } \\
\text { breast disease. Tissue } \\
\text { from } 33 \text { historical cases } \\
\text { added to control group }\end{array}$ & $14 \mathrm{~d}$ prior to surgery & $\begin{array}{l}\text { No difference in breast } \\
\text { epithelial proliferation } \\
\text { and apoptosis between } \\
\text { groups. Increase of pS2 } \\
\text { and apolipoprotein D } \\
\text { in soy intervention } \\
\text { group only. }\end{array}$ & $\begin{array}{l}\text { Expansion of } \\
\text { McMichael-Phillips } \\
\text { study. Considerable } \\
\text { variation in serum } \\
\text { isoflavone levels } \\
\text { between soy- } \\
\text { patients. }\end{array}$ \\
\hline $\begin{array}{l}\text { Sartippour } \\
\text { et al., } 2004 \text { (41) }\end{array}$ & $\begin{array}{l}\text { Isoflavone tablets. } \\
\text { Total dose: } 200 \mathrm{mg} / \mathrm{d}\end{array}$ & $\begin{array}{l}17 \text { breast cancer } \\
\text { patients received } \\
\text { intervention. } 26 \text { historic } \\
\text { breast cancer cases } \\
\text { acted as controls }\end{array}$ & $\begin{array}{l}23 \text { d (range 13-45) for } \\
\text { soy group and } 21 d \\
\text { (4-42) for historic } \\
\text { controls }\end{array}$ & $\begin{array}{l}\text { No significant } \\
\text { difference in } \\
\text { apoptosis/mitosis ratio } \\
\text { between groups. }\end{array}$ & $\begin{array}{l}\text { No information of } \\
\text { habitual diet of } \\
\text { historic controls had } \\
\text { been recorded }\end{array}$ \\
\hline $\begin{array}{l}\text { Palomares } \\
\text { et al., } 2004 \text { (42) }\end{array}$ & $\begin{array}{l}100 \mathrm{mg} / \mathrm{d} \text { isoflavone } \\
\text { tablet }\end{array}$ & $\begin{array}{l}23 \text { postmenopausal } \\
\text { cases with either in situ } \\
\text { or invasive breast } \\
\text { cancer randomised to } \\
\text { an isoflavone tablet or } \\
\text { placebo. Core biopsies } \\
\text { at baseline, } 6 \text { months } \\
\text { and } 12 \text { months time } \\
\text { points }\end{array}$ & 12 months & $\begin{array}{l}\text { Evaluation of biopsy } \\
\text { pairs from baseline } \\
\text { and } 6 \text { months for } 18 \\
\text { subjects showed no } \\
\text { significant increase in } \\
\text { Ki67 labelling index } \\
\text { between intervention } \\
\text { and control groups. }\end{array}$ & $\begin{array}{l}\text { Tissue biopsied from } \\
\text { contralateral breast. } \\
\text { Only preliminary } \\
\text { results published. No } \\
12 \text { month follow-up } \\
\text { data presented. }\end{array}$ \\
\hline $\begin{array}{l}\text { Thompson } \\
\text { et al., } 2005 \text { (44) }\end{array}$ & $\begin{array}{l}25 \mathrm{gr} \text { of ground } \\
\text { flaxseed in muffin }\end{array}$ & $\begin{array}{l}32 \text { postmenopausal } \\
\text { breast cancer patients. } \\
\text { Double-blind } \\
\text { randomised } \\
\text { intervention to either } \\
\text { flaxseed muffin or } \\
\text { normal muffin from } \\
\text { time of diagnostic core } \\
\text { biopsy till surgery }\end{array}$ & $\begin{array}{l}32 \mathrm{~d} \text { (mean) for } \\
\text { flaxseed group and } \\
39 \mathrm{~d} \text { (mean) for } \\
\text { placebo group }\end{array}$ & $\begin{array}{l}\text { Decrease in Ki67 } \\
\text { labelling index, } \\
\text { increase in apoptosis } \\
\text { and decrease in c- } \\
\text { erbB2 in flaxseed group } \\
\text { only. }\end{array}$ & $\begin{array}{l}\text { Although flaxseed is } \\
\text { rich in lignans it also } \\
\text { contains other } \\
\text { constituents. }\end{array}$ \\
\hline $\begin{array}{l}\text { Cheng et al., } \\
2007 \text { (43) }\end{array}$ & $\begin{array}{l}30 \mathrm{mg} \text { isoflavones as } \\
\text { part of fruit } \\
\text { flavoured drink }\end{array}$ & $\begin{array}{l}60 \text { healthy } \\
\text { postmenopausal } \\
\text { women. Double-blind } \\
\text { randomised } \\
\text { intervention to either } \\
\text { isoflavone drink or } \\
\text { placebo drink }\end{array}$ & 12 weeks & $\begin{array}{l}\text { No change in Ki67 in } \\
\text { breast biopsies } \\
\text { obtained by middle } \\
\text { needle biopsy before } \\
\text { and after intervention. }\end{array}$ & $\begin{array}{l}\text { Compliance } \\
\text { measured by urinary } \\
\text { analysis of } \\
\text { isoflavones }\end{array}$ \\
\hline
\end{tabular}

a PE: phytoestrogen.

alternatives to hormone replacement therapy for alleviating menopausal symptoms. At the same time all supplement use has increased. A recently published study ${ }^{54}$ conducted in Canada showed an increase in the use of complementary/alternative medicine products from 62\% in 1998 to
$70.6 \%$ in 2005 by breast cancer survivors. Amongst the most commonly used products in 2005 were flaxseed and soy.

These supplements are usually acquired without medical advice and their content is unregulated. In addition, only a 
few randomised, double blind, placebo-controlled trials have been carried out administering phytoestrogen-containing food or tablets to breast cancer survivors to evaluate their efficacy in terms of alleviating menopausal symptoms such as hot flushes. ${ }^{55-58}$ The duration of supplementation investigated in these studies ranged from 9 to 12 weeks during which no severe side-effects were experienced. There was no statistical difference in menopausal symptoms between the treatment and placebo groups in all four studies. These results are consistent with findings from a recent review of 32 randomised controlled trials in women with no malignant breast disease, of food or supplements containing at least $30 \mathrm{mg} / \mathrm{d}$ of isoflavones. The authors concluded that there was no evidence that the use of phytoestrogens treatments was effective in alleviating menopausal symptoms. ${ }^{59}$ Trials on breast cancer patients investigating the efficacy of the herb Black Cohosh have not been considered here as more recent work has not detected phytoestrogen chemicals in Black Cohosh. ${ }^{60}$

Isoflavones in soy have been consumed for centuries by Asian populations. In contrast, the western diet is richer in lignans than the Eastern diet but poorer in isoflavones. The introduction of isoflavones in the western diet has only occurred within the last few decades. Moreover, their presence in the diet has predominantly been in forms which are highly processed and depleted from many bioactive components rather than the traditional forms consumed in Far Eastern cultures. Interestingly, a study by Allred and colleagues ${ }^{61}$ showed that, unlike soy flour which had no effect, soy extracts and purified isoflavones resulted in growth stimulation of MCF-7 cells transplanted into ovariectomised athymic mice. The authors proposed that processing of soy increases its oestrogenicity. Consequently, breast cancer patients consuming soy extracts, isolated isoflavones or food containing highly processed soy could potentially be increasing their risk of recurrence. The genetic make-up of populations is adapted to dietary habits over long periods of time. It is therefore possible that the introduction of certain phytoestrogens, especially outside their food matrix as in the case of supplements or processed food ingredients, may have unpredictable biochemical and cytological long-term effects.

\section{Conclusion}

Data collected from human studies to date have not provided clear evidence that could be used to provide guidelines on phytoestrogen use for clinicians. Two meta-analyses of observational studies suggest a protective effect of phytoestrogens on breast cancer risk, with a third more recent one confining this only to Asian populations. However, early short-term intervention studies suggest a possible stimulatory effect of phytoestrogens on breast tissue, and this can only be confirmed by long-term human intervention studies. Questions also still remain regarding the influence of phytoestrogens in women at high risk of breast cancer and those with breast cancer, the interaction of these compounds with hormonal therapies for breast cancer and the use of these compounds as supplements isolated from the food matrix.
Although clear guidelines cannot yet be given to patients by clinicians, it is worth making breast cancer patients aware of the, as yet, undetermined role of phytoestrogens. Such discussions with patients need to take place soon after cancer diagnosis to pre-empt any decisions about dietary changes and supplement use involving phytoestrogens.

\section{Conflict of interest statement}

None declared.

R E F E R E N C E S

1. Deapen D, Liu L, Perkins C, Bernstein L, Ross RK. Rapidly rising breast cancer incidence rates among Asian-American women. Int J Cancer 2002;99:747-50.

2. Fletcher RJ. Food sources of phyto-estrogens and their precursors in Europe. Br J Nutr 2003;89(1):S39-43.

3. Setchell KD, Brown NM, Lydeking-Olsen E. The clinical importance of the metabolite equol-a clue to the effectiveness of soy and its isoflavones. J Nutr 2002;132:3577-84.

4. Rowland IR, Wiseman H, Sanders TA, Adlercreutz H, Bowey EA. Interindividual variation in metabolism of soy isoflavones and lignans: influence of habitual diet on equol production by the gut microflora. Nutr Cancer 2000;36(1):27-32.

5. Setchell KD, Lawson AM, Borriello SP, et al. Lignan formation in man-microbial involvement and possible roles in relation to cancer. Lancet 1981;2(8236):4-7.

6. Wu AH, Yu MC, Tseng CC, Pike MC. Epidemiology of soy exposures and breast cancer risk. Br J Cancer 2008;98(1): 9-14.

7. Trock BJ, Hilakivi-Clarke L, Clarke R. Meta-analysis of soy intake and breast cancer risk. J Natl Cancer Inst 2006;98(7):459-71.

8. Qin LQ Xu JY, Wang PY, Hoshi K. Soyfood intake in the prevention of breast cancer risk in women: a meta-analysis of observational epidemiological studies. J Nutr Sci Vitaminol (Tokyo) 2006;52(6):428-36.

9. Thanos J, Cotterchio M, Boucher BA, Kreiger N, Thompson LU. Adolescent dietary phytoestrogen intake and breast cancer risk (Canada). Cancer Causes Control 2006;17(10):1253-61.

10. Wu AH, Wan P, Hankin J, Tseng CC, Yu MC, Pike MC. Adolescent and adult soy intake and risk of breast cancer in Asian-Americans. Carcinogenesis 2002;23(9):1491-6.

11. Shu XO, Jin F, Dai $Q$, Wen W, et al. Soyfood intake during adolescence and subsequent risk of breast cancer among Chinese women. Cancer Epidemiol Biomarkers Prev 2001;10(5):483-8.

12. Lamartiniere CA, Cotroneo MS, Fritz WA, Wang J, MentorMarcel R, Elgavish A. Genistein chemoprevention: timing and mechanisms of action in murine mammary and prostate. $J$ Nutr 2002;132(3):552S-8S.

13. Fink BN, Steck SE, Wolff MS, et al. Dietary flavonoid intake and breast cancer risk among women on Long Island. Am J Epidemiol 2007;165(5):514-23.

14. McCann SE, Muti P, Vito D, Edge SB, Trevisan M, Freudenheim JL. Dietary lignan intakes and risk of pre- and postmenopausal breast cancer. Int J Cancer 2004;111(3):440-3.

15. Dos Santos Silva I, Mangtani P, McCormack V, Bhakta D, McMichael AJ, Sevak L. Phyto-oestrogen intake and breast cancer risk in South Asian women in England: findings from a population-based case-control study. Cancer Causes Control 2004;15(8):805-18. 
16. Linseisen J, Piller R, Hermann S, Chang-Claude J. Dietary phytoestrogen intake and premenopausal breast cancer risk in a German case-control study. Int J Cancer 2004;110(2):284-90.

17. McCann SE, Moysich KB, Freudenheim JL, Ambrosone CB, Shields PG. The risk of breast cancer associated with dietary lignans differs by CYP17 genotype in women. J Nutr 2002;132(10):3036-41.

18. Horn-Ross PL, John EM, Lee M, et al. Phytoestrogen consumption and breast cancer risk in a multiethnic population: the Bay Area Breast Cancer Study. Am J Epidemiol 2001;154(5):434-41.

19. Horn-Ross P, Hoggatt KJ, West DW, et al. Recent diet and breast cancer risk: the California Teachers Study (USA). Cancer Causes Control 2002;13(5):407-15.

20. Keinan-Boker L, van Der Schouw YT, Grobbee DE, Peeters PH. Dietary phytoestrogens and breast cancer risk. Am J Clin Nutr 2004;79(2):282-8.

21. Touillaud MS, Thiebaut ACM, Fournier A, Niravong M, Boutron-Ruault MC, Clavel-Chapelon F. Dietary lignan intake and postmenopausal breast cancer risk by estrogen and progesterone receptor status. J Natl Cancer Inst 2007;99(6):475-86.

22. Ritchie MR, Morton MS, Deighton N, Blake A, Cummings JH. Plasma and urinary phyto-oestrogens as biomarkers of intake: validation by duplicate diet analysis. Br J Nutr 2004;91(3):447-57.

23. Grace PB, Taylor JI, Low YL, et al. Phytoestrogen concentrations in serum and spot urine as biomarkers for dietary phytoestrogen intake and their relation to breast cancer risk in European prospective investigation of cancer and nutrition-norfolk. Cancer Epidemiol Biomarkers Prev 2004;13(5):698-708.

24. Verheus M, van Gils CH, Keinan-Boker L, Grace PB, Bingham $\mathrm{PH}$, Peeters $\mathrm{PH}$. Plasma phytoestrogens and subsequent breast cancer risk. J Clin Oncol 2007;25(6):648-55.

25. Kilkkinen A, Virtamo J, Vartiainen E, et al. Serum enterolactone concentration is not associated with breast cancer risk in a nested case-control study. Int J Cancer 2004;108(2):277-80.

26. Zeleniuch-Jacquotte A, Adlercreutz H, Shore RE, et al. Circulating enterolactone and risk of breast cancer: a prospective study in New York. Br J Cancer 2004;91(1):99105.

27. Hulten $\mathrm{K}$, Winkvist A, Lenner P, Johansson R, Adlercreutz H, Hallmans G. An incident case-referent study on plasma enterolactone and breast cancer risk. Eur J Nutr 2002;41(4):168-76.

28. Piller R, Chang-Claude J, Linseisen J. Plasma enterolactone and genistein and the risk of premenopausal breast cancer. Eur J Cancer Prev 2006;15(3):225-32.

29. Olsen A, Knudsen KE, Thomsen BL, et al. Plasma enterolactone and breast cancer incidence by estrogen receptor status. Cancer Epidemiol Biomarkers Prev 2004;13(12):2084-9.

30. Boccardo F, Lunardi G, Guglielmini P, et al. Serum enterolactone levels and the risk of breast cancer in women with palpable cysts. Eur J Cancer 2004;40(1):84-9.

31. Pietinen P, Stumpf K, Männistö S, Kataja V, Uusitupa M, Adlercreutz H. Serum enterolactone and risk of breast cancer: a case-control study in eastern Finland. Cancer Epidemiol Biomarkers Prev 2001;10(4):339-44.

32. McCann SE, Kulkarni S, Trevisan M, et al. Dietary lignan intakes and risk of breast cancer by tumor estrogen receptor status. Breast Cancer Res Treat 2006;99(3):309-11.

33. Den Tonkelaar I, Keinan-Boker L, Veer PV, et al. Urinary phytoestrogens and postmenopausal breast cancer risk. Cancer Epidemiol Biomarkers Prev 2001;10(3):223-8.
34. Dai Q, Franke AA, Yu H, et al. Urinary phytoestrogen excretion and breast cancer risk: evaluating potential effect modifiers endogenous estrogens and anthropometrics. Cancer Epidemiol Biomarkers Prev 2003;12(6):497-502.

35. Dai Q, Franke AA, Jin F, et al. Urinary excretion of phytoestrogens and risk of breast cancer among Chinese women in Shanghai. Cancer Epidemiol Biomarkers Prev 2002;11(9):815-21.

36. Ingram D, Sanders K, Kolybaba M, Lopez D. Case-control study of phyto-oestrogens and breast cancer. Lancet 1997;350(9083):990-4.

37. Adlercreutz H, Fotsis T, Heikkinen R, et al. Excretion of the lignans enterolactone and enterodiol and of equol in omnivorous and vegetarian postmenopausal women and in women with breast cancer. Lancet 1982;2(8311):1295-9.

38. Petrakis NL, Barnes S, King EB, et al. Stimulatory influence of soy protein isolate on breast secretion in pre- and postmenopausal women. Cancer Epidemiol Biomarkers Prev 1996;5(10):785-94.

39. McMichael-Phillips DF, Harding C, Morton M, et al. Effects of soy-protein supplementation on epithelial proliferation in the histologically normal human breast. Am J Clin Nutr 1998;68(6 ):1431S-5S.

40. Hargreaves DF, Potten CS, Harding C, et al. Two-week dietary soy supplementation has an estrogenic effect on normal premenopausal breast. J Clin Endocrinol Metab 1999;84(11):4017-24.

41. Sartippour MR, Rao JY, Apple S, et al. A pilot clinical study of short-term isoflavone supplements in breast cancer patients. Nutr Cancer 2004;49(1):59-65.

42. Palomares MR, Hopper L, Goldstein L, et al. Effect of soy isoflavones on breast proliferation in postmenopausal breast cancer survivors. Breast Cancer Res Treat 2004;88(1): S149.

43. Cheng G, Wilczek B, Warner M, Gustafsson JA, Landgren BM. Isoflavone treatment for acute menopausal symptoms. Menopause 2007;14(3 Pt 1):468-73.

44. Thompson LU, Chen JM, Li T, Strasser-Weippl K, Goss PE. Dietary flaxseed alters tumor biological markers in postmenopausal breast cancer. Clin Cancer Res 2005;11(10):3828-35.

45. Boyd NF, Lockwood GA, Byng JW, Trichler DL, Yaffee MJ. Mammographic densities and breast cancer risk. Cancer Epidemiol Biomark Prev 1998;7:1133-44.

46. Maskarinec G, Williams AE, Carlin L. Mammographic densities in a one-year isoflavone intervention. Eur J Cancer Prev 2003;12(2):165-9.

47. Atkinson C, Warren RM, Sala E, et al. Red-clover-derived isoflavones and mammographic breast density: a doubleblind, randomized, placebo-controlled trial. Breast Cancer Res 2004;6(3):R170-9.

48. Maskarinec G, Takata Y, Franke AA, Williams AE, Murphy SP. A 2-year soy intervention in premenopausal women does not change mammographic densities. J Nutr 2004;134(11): 3089-94.

49. Stuedal A, Gram IT, Bremnes Y, Adlercreutz H, Veierød MB, Ursin G. Plasma levels of enterolactone and percentage mammographic density among postmenopausal women. Cancer Epidemiol Biomarkers Prev 2005;14(9):2154-9.

50. Nagel G, Mack U, von Fournier D, Linseisen J. Dietary phytoestrogen intake and mammographic density - results of a pilot study. Eur J Med Res 2005;10(9):389-94.

51. Fink BN, Steck SE, Wolff MS, et al. Dietary flavonoid intake and breast cancer survival among women on Long Island. Cancer Epidemiol Biomarkers Prev 2007;16(11):2285-92.

52. Boyapati SM, Shu XO, Ruan ZX, et al. Soyfood intake and breast cancer survival: a followup of the Shanghai Breast Cancer Study. Breast Cancer Res Treat 2005;92(1):11-7. 
53. Liu B, Edgerton S, Yang X, et al. Low-dose dietary phytoestrogen abrogates tamoxifen-associated mammary tumor prevention. Cancer Res 2005;65(3):879-86.

54. Boon HS, Olatunde F, Zick SM. Trends in complementary/ alternative medicine use by breast cancer survivors: comparing survey data from 1998 and 2005. BMC Women's Health 2007;7:4.

55. MacGregor CA, Canney PA, Patterson G, McDonald R, Paul J. A randomised double-blind controlled trial of oral soy supplements versus placebo for treatment of menopausal symptoms in patients with early breast cancer. Eur J Cancer 2005;41(5):708-14.

56. Nikander E, Kilkkinen A, Metsä-Heikkilä M, et al. A randomized placebo-controlled crossover trial with phytoestrogens in treatment of menopause in breast cancer patients. Obstet Gynecol 2003;101(6):1213-20.

57. Van Patten CL, Olivotto IA, Chambers GK, et al. Effect of soy phytoestrogens on hot flashes in postmenopausal women with breast cancer: a randomized, controlled clinical trial. J Clin Oncol 2002;20(6):1449-55.

58. Quella SK, Loprinzi CL, Barton DL, et al. Evaluation of soy phytoestrogens for the treatment of hot flashes in breast cancer survivors: a North Central Cancer Treatment Group Trial. J Clin Oncol 2000;18(5):1068-74.

59. Lethaby AE, Brown J, Marjoribanks J, Kronenberg F, Roberts H, Eden J. Phytoestrogens for vasomotor menopausal symptoms. Cochrane Database Syst Rev 2007(4):CD001395.
60. Jiang B, Kronenberg F, Balick MJ, Kennelly EJ. Analysis of formononetin from black cohosh (Actaea racemosa). Phytomedicine 2006;13(7):477-86.

61. Allred CD, Allred KF, Ju YH, Goeppinger TS, Doerge DR, Helferich WG. Soy processing influences growth of estrogendependent breast cancer tumors. Carcinogenesis 2004;25(9):1649-57.

62. Piersen CE. Phytoestrogens in botanical dietary supplements: implications for cancer. Integr Cancer Ther 2003;2(2):120-38.

63. Magee PJ, McGlynn H, Rowland IR. Differential effects of isoflavones and lignans on invasiveness of MDA-MB-231 breast cancer cells in vitro. Cancer Lett 2004;208(1):35-41.

64. Kousidou OC, Mitropoulou TN, Roussidis AE, Kletsas D, Theocharis AD, Karamanos NK. Genistein suppresses the invasive potential of human breast cancer cells through transcriptional regulation of metalloproteinases and their tissue inhibitors. Int J Oncol 2005;26(4):1101-9.

65. Chen J, Hui E, Ip T, Thompson LU. Dietary flaxseed enhances the inhibitory effect of tamoxifen on the growth of estrogendependent human breast cancer (mcf-7) in nude mice. Clin Cancer Res 2004;10(22):7703-11.

66. Wang L, Chen J, Thompson LU. The inhibitory effect of flaxseed on the growth and metastasis of estrogen receptor negative human breast cancer xenograftsis attributed to both its lignan and oil components. Int J Cancer 2005;116(5): 793-8. 